\title{
Krepitev moči ob reševanju problemov
}

\author{
Vita Poštuvan \\ Univerza na Primorskem \\ vita.postuvan@upr.si
}

Delo psihologa se pogosto osredotoča na reševanje problemov, diagnosticiranje (duševnih) motenj in težav ter postavljanje ciljev intervencij za njihovo reševanje. Večino časa se delo psihologa nanaša na negativne vidike vsakodnevnega življenja. Pogosto v tem delu spregledamo moči oz. kvalitete ljudi, predvsem tiste, ki se nanašajo na njihov značaj in vrednote. Nevede se na ta način tudi pri lastnih refleksijah osredotočamo na pomanjkljivosti in stvari, s katerimi nismo zadovoljni. Pri svojem delu lahko opazimo, da nekatere stvari odlašamo, drugje se z željo po popolnosti ženemo za doseganjem rezultatov. Redkeje opazimo, da smo pri intervencijah ali v odnosih dobro uporabili svoje znanje in modrost, trezno presodili situacijo, imeli pogum za implementacijo naučenega, sledili vrednotam humanosti, pravičnosti ali celo prepoznali lepoto in smisel v svojem delu. Osebne moči lahko razdelimo glede na to, ali so osredotočene na inter- oz. intrapersonalne značilnosti, in glede na njihovo kognitivno oz. čustveno obarvanost. Z njihovim poznavanjem si lahko bolje pomagamo v skrbi zase in evalvaciji svojega dela.

\section{Izhodišča}

Pridi pogledat v naš novi klub, sami težki pacienti vrženi na kup, vsakega muči vsaj ena težava, vsak bo prisegu da njegova je prava ...

Zmelkoow

Delo psihologa se pogosto osredotoča na reševanje problemov, diagnosticiranje (duševnih) motenj in težav ter postavljanje ciljev intervencij za njihovo reševanje.

\section{Reševanje problemov}

Kot problem se navadno opredeli življenjska situacija ali naloga, ki zahteva prilagojeno delovanje, rešitev problema pa kot odgovor na problemsko situacijo, pri čemer so pozitivne posledice kar največje in negativne čim manjše. Pri tem je ključen proces reševanja problemov, ki ga razumemo kot proces oblikovanja ali odkrivanja rešitev. Stili reševanja problemov so različni glede na situacijo, saj se na enostavne probleme odzovemo drugače kot na kompleksne. Razlika je tudi, ali govorimo o kriznih intervencijah ali o težavah, ki so dolgoročnejše narave. 
Različni pristopi reševanja problemov se nanašajo tudi na to, ali so problemi:

- neosebni (finančni, lastništvo);

- osebni (čustva, telo, vedenje);

- problemi v odnosih (partnerski, družinski);

- problemi v okolici, družbi.

V splošnem velja, da so problemi za posameznika stresnejši, ko sta ogrožena dobrobit in varnost oseb, ter manj stresni, ko imajo ljudje večji občutek zmožnosti reševanja situacij in resursov za pomoč.

Pristopi k reševanju problemov so lahko usmerjeni v situacije, in sicer se tega poslužujemo takrat, ko so situacije rešljive. $V$ primerih, ko to ni mogoče, uporabimo veščine soočanja. $V$ pomoč pa so nam lahko tudi kognitivne strategije, ki omogočajo drugačen pogled na situacijo in večajo optimizem (Mahoney, 2006).

Mahoney (2006) reševanja problemov opredeli z angleško kratico "S C IENCE«, in sicer po fazah:

- opredeliti problem (specify the problem);

- zbrati informacije (collect information);

- prepoznati možne vzroke (identify possible causes);

- preučiti možne rešitve (examine possible solutions);

- fokusirati rešitve in poskusiti (narrow solutions and experiment);

- primerjati napredek (compare your progress);

- razširiti, popraviti ali zamenjati rešitev oz. strategijo (extend, revise or replace your solution).

\section{Značajske moči}

Reševanje problemov je lahko vedno tudi priložnost za rast, učenje veščin in kompetenc. Pri tem nam lahko pomaga tudi usmerjanje pozornosti na pozitivne kvalitete in na značajske moči, ki jih imamo $v$ danem trenutku ali na splošno v življenju.

Značajske moči so stabilne osebnostne poteze, ki se manifestirajo skozi mišljenje, čustva, motivacijo in vedenje. Če so izražene v ravnotežju, so navadno moralno sprejete ter delujejo pozitivno na osebo in druge. So ključni gradniki človeške dobrote, avtentičnosti in rasti.

V okviru inštituta VIA (ki pomeni vrednote in izvedba oz. values and action) je 55 strokovnjakov sodelovalo v triletnem projektu, v okviru katerega 
so pregledali pozitivne človeške kvalitete, ki so zapisane v različnih filozofskih usmeritvah, tekstih o etiki, poučevanju morale, psihologiji in teologiji za zadnjih 2.500 let. Na podlagi tega so sestavili vprašalnik značajskih moči, ki sta ga reševala 2 milijona ljudi iz vsake države sveta. Raziskovalci so na različne načine zagotovili dobre psihometrične lastnosti vprašalnika (Niemiec, 2013; https://www.viacharacter.org). Vprašalnik vsebuje šest temeljnih dimenzij, in sicer so to (s poddimenzijami):

1. Modrost - kognitivne moči, ki se nanašajo na pridobivanje in uporabo znanja (s poddimenzijami ustvarjalnost, radovednost, kritično mišljenje, ljubezen do učenja, perspektiva).

2. Pogum - emocionalne moči, ki se nanašajo na voljo za doseganje ciljev navkljub oviram (notranjega ali zunanjega značaja), s poddimenzijami pogum, vztrajnost, pristnost (avtentičnost, iskrenost), vnema (entuziazem, energija).

3. Humanost - medosebne moči, ki se nanašajo na prijaznost do drugih (s poddimenzijami ljubezen, prijaznost (in radodarnost), socialna inteligentnost).

4. Pravičnost - moči, ki so temelj zdravega življenja v skupnosti, kamor sodijo poddimenzije timsko delo (pripadnost skupini), poštenost (pravičnost), vodenje.

5. Preudarnost - moči, ki preprečujejo ekscese (poddimenzije odpuščanje (in usmiljenje), skromnost, previdnost, samokontrola (samouravnavanje)).

6. Transcendenca - moči, ki povezujejo s širšim univerzumom in pomagajo osmišljati (poddimenzije cenjenje lepote in odličnosti, hvaležnost, humor in igrivost, upanje (optimizem), duhovnost (občutek smisla)).

Vsak posameznik ima značilne moči. To so tiste, ki jih sami naravno spodbujamo in razvijamo, ki nas zaznamujejo. So pomembne pri doseganju naših življenjskih ciljev in želja (Niemiec, 2013).

\section{Kompetence za krepitev moči ob reševanju problemov}

Večino časa se psihologi ukvarjajo $\mathrm{z}$ negativnimi vidiki vsakodnevnega življenja. Lahko se zgodi, da v tem delu spregledajo moči oz. lastne kvalitete, pomembne pozitivne vidike značaja in vrednote. Nevede se na ta način tudi pri lastnih refleksijah osredotočajo na pomanjkljivosti in stvari, s katerimi niso zadovoljni. Zato je dobrodošlo, da: 
Preglednica 1 Pregled ključnih kompetenc in znanj za krepitev moči ob reševanju problemov

\begin{tabular}{ll}
\hline Znanja & Kompetence \\
\hline - Teorije reševanja problemov & - Razvoj spretnosti, tehnik in načinov za \\
- Opredelitev in teoretična izhodišča teo- & pomoč v problemskih situacijah \\
$\begin{array}{l}\text { rije značajskih moči } \\
\text { - Spretnosti prepoznave problemov in nji- }\end{array}$ & - Analiza načinov reševanja problemov \\
hovega reševanja & - Reflektiranje reševanja problemov v kon- \\
- Spretnosti reflektiranja in krepitve svojih & tekstu značilnih moči \\
značajskih moči & Prenos tehnik iz izkustvenega učenja na \\
& uporabnike psiholoških storitev \\
\hline
\end{tabular}

- dobro poznajo svoje značilne moči;

- poznajo načine, kako krepiti svoje značilne moči;

- se odzivajo na situacije, ki potrebujejo posebno pozornost;

- skrbijo za udejanjanje načinov krepitve značilnih moči;

- reflektirajo nove izkušnje in reševanje problemov v kontekstu značilnih moči.

Za krepitev moči ob reševanju problemov lahko psiholog in tudi drugi strokovnjaki s sorodnih področij na ravni primarnih kompetenc razvijajo znanja, tehnike in načine, s katerimi si lahko pomagajo $v$ takšnih situacijah. Gre za tehnike, ki na eni strani strokovnjaku pomagajo pri lastnih problemih, hkrati pa so tudi tehnike za uporabnike njihovih storitev. Podrobnejše v preglednici 1. Spodnje aktivnosti lahko pomagajo pri razvijanju opisanih kompetenc in znanj.

\section{Prepoznati problem}

Kadar nas kak problem zelo bremeni, lahko opazimo, da stvari odlašamo, premlevamo reči ali se z željo po popolnosti ženemo za doseganjem rezultatov. V takšnih situacijah je dobrodošlo, da raziščemo kvalitete problema. Spodnja vaja oz. aktivnost lahko pri tem pomaga.

\section{Aktivnost: Problem, ki vas bremeni}

Bodite pozorni na neprijeten dogodek oz. problem, ki vas bremeni. Uporabite spodaj navedena vprašanja, da usmerite svojo pozornost na podrobnosti izkušnje (prilagojeno po Poštuvan in Tančič Grum, 2015). Pri tem ni nujno, da gre za zelo osebno stvar, temveč lahko refleksijo pričnete z manjšimi težavami in šele kasneje to uporabite pri kompleksnejših problemih.

Zabeležite 7 dni v tednu, kako doživljate vaš problem in vaše razpoloženje ob tem (preglednica 2). Ko nas nek problem preplavi, imamo včasih 
Preglednica 2 Primer refleksije problema

\begin{tabular}{|c|c|c|c|c|}
\hline $\begin{array}{l}\text { Za katero iz- } \\
\text { kušnjo oz. pro- } \\
\text { blem gre? }\end{array}$ & $\begin{array}{l}\text { Kakšni so vaši } \\
\text { telesni občutki } \\
\text { med to izku- } \\
\text { šnjo (opišite po- } \\
\text { drobno)? }\end{array}$ & $\begin{array}{l}\text { Katera razpolo- } \\
\text { ženja in čustva } \\
\text { spremljajo pro- } \\
\text { blem? }\end{array}$ & $\begin{array}{l}\text { Katere misli so } \\
\text { prisotne ob pro- } \\
\text { blemu? }\end{array}$ & $\begin{array}{l}\text { Katere misli se } \\
\text { vam porajajo } \\
\text { zdaj, ko to pi- } \\
\text { šete? }\end{array}$ \\
\hline $\begin{array}{l}\text { Zadnje čase sem } \\
\text { zelo napet za- } \\
\text { radi vseh obvez- } \\
\text { nosti. }\end{array}$ & $\begin{array}{l}\text { Razbijanje srca, } \\
\text { zategnjenost v } \\
\text { vratu in rame- } \\
\text { nih, hoja sem in } \\
\text { tja, napetost v } \\
\text { želodcu. }\end{array}$ & $\begin{array}{l}\text { Jeza, nemoč, } \\
\text { razburjenost, } \\
\text { skrb. }\end{array}$ & $\begin{array}{l}\text { "Kako bom vse } \\
\text { zmogel?« »Za } \\
\text { vse sem sam/- } \\
\text { a." }\end{array}$ & $\begin{array}{l}\text { "Upam, da se } \\
\text { mi to ne bo zgo- } \\
\text { dilo še kdaj.» }\end{array}$ \\
\hline $\begin{array}{l}\text { Zaradi prepira z } \\
\text { domačimi sem } \\
\text { zamudil/-a celo } \\
\text { na pomemben } \\
\text { sestanek. }\end{array}$ & & & $\begin{array}{l}\text { „Kaj bodo rekli, } \\
\text { ker sem zamu- } \\
\text { dil/a na sesta- } \\
\text { nek?» }\end{array}$ & \\
\hline
\end{tabular}

Kaj je vaš glavni pomislek ob reševanju tega problema danes?

Katero moč v tem trenutku potrebujete, da ga rešite?

občutek, da težave vztrajajo ves čas. Opisana vaja nam lahko pokaže, da obstajajo spremembe in razlike $\mathrm{v}$ doživljanju problema $\mathrm{v}$ različnih situacijah, četudi so te razlike majhne in jih verjetno brez podrobne refleksije ne bi zaznali.

\section{Koraki reševanja problemov}

Pri reševanju problemov nam lahko pomaga zavedanje, da je to proces. Naše spretnosti (in kompetence) zato zajemajo ocenjevanje potreb oz. situacije ter določitev ciljev in alternativ, ki so na voljo. Pri tem si lahko pomagate s spodnjo tehniko in primeri vprašanj (prilagojeno po Šinigoj Batistič, 2007; Mahoney, 2006).

1. Prepoznati in izbrati problem.

- Premislite, ali je vaš problem realen ali gre za izkrivljeno percepcijo situacije. Kako vidijo to (ali podobno) situacijo drugi ljudje?

- Če prepoznate več problemov, ki se pojavljajo hkrati, pričnite z reševanjem tistega, ki je najlažji in ključen za vas.

- Poskusite čim jasneje definirati problem in opredelite okoliščine glede problema, npr. zabeležite, kako dolgo se problem že pojavlja, kako intenziven je, kako se ob tem počutite itd.

2. Iskanje alternativ oz. rešitev. 
- Z metodo nevihte možganov poskusite generirati šest do osem (lahko pa tudi do petnajst) možnih rešitev vašega problema, pri čemer se ne obremenjujte $z$ vsebino rešitev. Dajte domišljiji prosto pot, saj je v tem koraku kvantiteta idej pomembnejša od kvalitete.

- Spodbujajte iskanje rešitev. Morda lahko poskusite tako, da se distancirate od situacije, postavljate (sebi ali osebi, s katero izvajate tehniko) kreativna vprašanja (o tem, kako bi kdo drug rešil situacijo, kako bi na situacijo gledali čez 30 let, kako bi bilo, če bi situacijo rešili v določenih čustvenih situacijah, npr. v jezi, sočutju itd.).

- Ne pozabite, da je lahko ena izmed možnih alternativ tudi odločitev, da vse ostane tako, kot je. Kadar to zavestno izberemo, je počutje drugačno, kot če imamo občutek, da smo v situacijo pahnjeni brez kontrole.

3. Prednosti in pomanjkljivosti vsake alternative.

- V tem koraku za vsako od zapisanih alternativ zapišite, katere so njene prednosti in katere so pomanjkljivosti.

- Preverite, morda so ob alternativi prisotne specifične misli, čustva, ki delujejo kot prednosti ali pomanjkljivosti oz. kot spodbuda ali ovira za izbiro posamezne alternative.

- Preverite kratko- in dolgoročne učinke zase in druge pri vsaki alternativi. Včasih se zgodi, da ima kakšna alternativa najprej negativno konotacijo (npr. je zelo težka odločitev z veliko čustvenega naboja), a lahko na dolgi rok pozitivno vpliva na posameznikovo življenje.

- Občutek zaupanja v uspeh in kompetentnosti za izvedbo alternativ so pomemben dejavnik pri tehtanju prednosti in pomanjkljivosti.

4. Izbor alternative.

- Glede na 3. korak alternative ponderiramo (jim pripišemo različno težo, npr. v obliki ocene od 1 do 5 glede na prednosti in pomanjkljivosti).

- Na podlagi refleksije rangiramo vrstni red alternativ in izberemo rešitev, ki se nam $v$ danem trenutku zdi najsmiselnejša.

- Včasih se zgodi, da ne najdemo ene "najboljše« rešitve. V takem primeru lahko naslednje korake opredelimo za dve alternativi. 
- Ob izboru alternative naredimo načrt izvedbe alternative; torej opredelimo, kdo, kako in kdaj bo kaj naredil.

5. Izvedba.

- Načrt izvedbe je navadno bolj dodelan v bolj negotovih situacijah oz. v situacijah, ki nam predstavljajo izziv. Kadar imamo občutek, da situacija ni zelo tvegana ter da imamo zadostne sposobnosti soočanja, smo navadno odprti tudi za več fleksibilnosti in odprtosti pri izvedbi.

- Ob izvedbi rešitve si zabeležite učinek.

6. Evalvacija.

- Ob izvedeni alternativi je dobro reflektirati celoten proces. Razmislite, kako uspešna je bila rešitev in ali je bilo potrebno prilagoditi načrt izvedbe. Kaj vas je izkušnja naučila?

- Če rezultat ni uspešen, se vrnemo na korak 2.

\section{Razvijanje moči ob reševanju problemov}

Ko $\mathrm{v}$ procesu reševanja problemov uporabimo svoje znanje in modrost zato, da trezno presodimo situacijo in dobimo pogum za implementacijo naučenega, lažje sledimo vrednotam humanosti, pravičnosti ali tako celo prepoznamo lepoto in smisel $\mathrm{v}$ svojem delu oz. procesu reševanja problema. Značilne značajske moči nam lahko pomagajo pri tem.

Osebne moči lahko razdelimo glede na to, ali so osredotočena na interoz. intrapersonalne značilnosti in glede na njihovo kognitivno oz. čustveno obarvanost. $Z$ njihovim poznavanjem si lahko boljše pomagamo v skrbi zase in evalvaciji svojega dela. Za lastno oceno si lahko pomagate z vprašalnikom značajskih moči VIA, ki ga najdete na spletni strani https://www.viacharacter.org. Vprašalnik boste na spletni strani našli tudi v slovenskem jeziku, prav tako vam na podlagi rezultatov spletna platforma sama kreira osebni profil. Lahko pa sami razmislite in rangirate moči $\mathrm{v}$ preglednici $3 \mathrm{v}$ skladu s poznavanjem samega sebe.

Če je težko prepoznati vaše značajske moči preko vprašalnika ali liste, si lahko pomagate $\mathrm{z}$ aktivnostjo prepoznave moči (prilagojena po Niemiec, 2013).

\section{Aktivnost: Prepoznava moči v situaciji}

Vajo lahko naredite v paru, če imate to možnost. Če pa te možnosti ni, lahko namesto pripovedovanja zgodbo oz. naloge tudi zapišete in poskusite sami sebi postaviti ključna vprašanja za razmislek. 
Preglednica 3 Značajske moči

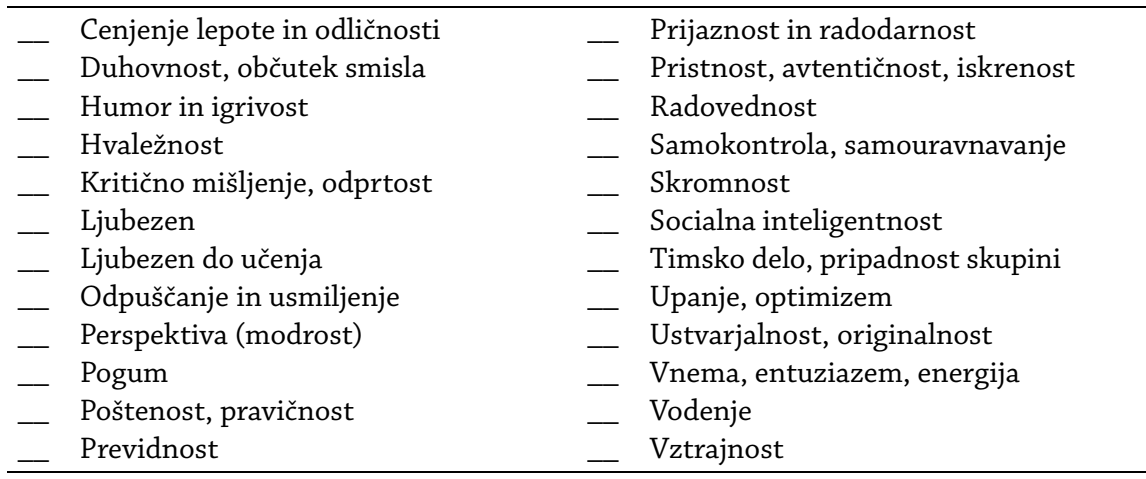

Zapišite oz. pripovedujte zgodbo o dogodku, ko ste se zares izkazali. Naj bo to nekaj, kjer ste res pokazali vaše najboljše kvalitete in najboljše značilnosti, kar jih premorete. Če izvajate vajo v paru, naj druga oseba ne posega v zgodbo s svojimi interpretacijami ali komentarji, temveč naj vas samo spodbuja z odprtimi vprašanji o tem, kaj se je dogajajo, kdo je bil vključen, kako se je dogodek razpletel. Tudi če bo pripovedovalec za nekaj trenutkov ostal brez besed, dovolite čas za to.

Ko se zaključi zgodba, reflektirajte zgoraj zapisane značajske moči, ki so se pokazale v tem dogodku. Ponudite medsebojno razlago, kako ste značajske moči prepoznali in morda premislite, zakaj so bile ključne v situaciji.

Premislite:

- Kako skladno je vaše zaznavanje značajskih moči s tem, kar je prepoznala druga oseba? Če ste rešili vprašalnik vi A, pomislite, koliko so rezultati vprašalnika skladni z lastno percepcijo sebe.

- Pomislite na tri najbolj izpostavljene moči. Kako se kažejo sicer v vašem vsakdanjiku? Naštejte primere za to.

- Pomislite na vaše tri najslabše moči. Kako se to kaže v vašem vsakdanjiku?

- Pomislite na situacijo, ko rešujete kak problem. Katere od lastnih moči bi lahko uporabili sebi v prid pri reševanju problema?

- Kako bi lahko še razvijali tiste moči, ki trenutno pri vas niso dovolj močne?

Nato lahko vlogi zamenjate in ob koncu menjave premislite še, ali je bilo značajske moči lažje opaziti pri sebi ali pri drugi osebi. Ste lažje opazili moči, ko ste govorili ali poslušali? Ste katere moči naravno uporabljali? 
Vsi imamo možnost izraziti vse značajske moči, vendar naj bi imela glede na študije le $1 / 3$ ljudi polno ozaveščen pomen svojih moči. Študije so pokazale povezavo med izraženostjo naših značilnih moči in občutkom sreče, zavzetosti, osmišljenosti ter manjšo stopnjo depresije. Kratki eksperimenti so celo pokazali, da če so ljudje namenoma razvijali oz. uporabljali eno značilno moč na nov način sedem dni zapored, se jim je pomembno povečal občutek sreče in znižala raven depresije. Učinek te vaje je bil viden tudi po 6 mesecih. Razvijanje moči lahko izvajamo tudi namenoma, npr. $\mathrm{s}$ spodnjo aktivnostjo (prilagojeno po Niemiec, 2013).

\section{Aktivnost: Razvijanje moči}

Izberite tisto moč, ki jo želite pri sebi okrepiti oz. pogosteje uporabljati. Lahko tudi pomislite na kak problem, ki ga želite rešiti, in poskusite ugotoviti, katero moč bi potrebovali, da bi se boljše soočali s procesom reševanja.

Poskusite raziskovati možnosti uporabe izbrane moči pri tem problemu. Če izvajate vajo v paru, naj vam druga oseba zastavlja vprašanja, ki spodbujajo, so iskrena, odprta, pomagajo iskati in odpirati refleksijo. Lahko si pomagate s spodnjimi vprašanji:

- Kaj si želite? Morda je razvijanje značajskih moči samo po sebi cilj, lahko pa je cilj način delovanja v skladu s temi močmi, kar bo pomagalo pri reševanju problema.

- Raziskujte, kako in kje že uporabljate to moč. Kje ste jo nazadnje uporabili? Kako ste se ob tem počutili?

- Sanje: Kako bi vaš najboljši jaz rešil situacijo? Brez presojanja ali vsakodnevnih ovir pomislite, kako bi bilo, če bi to moč že imeli.

- Načrtujte majhne korake, kako bi to moč lahko uporabil že kmalu.

- Podajte povratne informacije, podporo in zaupanje v moč implementacije.

\section{Zaključek}

Glede na to, kako občutimo posamezne težke situacije v življenju, sovplivata ocena neugodnosti oz. nevarnosti situacije in lastne učinkovitosti reševanja te situacije. Če doživljamo nizek nivo stresa in imamo visoko sposobnost soočanja, se počutimo varni in situacija nima posledic na sliko o nas samih. Kadar občutimo veliko tveganja in malo sposobnosti soočanja s situacijo, občutimo nevarnost, kar pogosto privede do izogibanja situaciji (za trenutno zmanjševanje tesnobe) ali dolgoročno zniža občutek samoučinkovitosti. Kadar navkljub zaznanemu visokemu tveganju ali neugodni 
situaciji občutimo, da imamo visoko sposobnost soočanja, lahko reševanje problema vidimo kot izziv, kar nam dolgoročno poveča občutek samoučinkovitosti (Leahy in Holland, 200o). Razvijanje lastnih značajskih moči nam daje možnost razvijanja lastnih potencialov tako pri skrbi za lastno duševno zdravje kot pri prenosu tega na deležnike psihologovih storitev.

\section{Literatura}

Leahy, R. L., in Holland, S. J. (2000). Treatment plans and interventions for depression and anxiety disorders. The Guilford Press.

Mahoney, M. J. (2006). Constructive psychotherapy: A practical guide. The Guilford Press.

Niemiec, R. M. (2013). Mindfulness and character strengths: A practical guide to flourishing. Hogrefe Publishing.

Poštuvan, V., in Tančič Grum, A. (2015). Program NARA: moč strokovnjakom skozi čuječnost. Založba Univerze na Primorskem.

Šinigoj Batistič, I. (2007). Reševanje problemov. V N. Anič in P. Janjušević (ur.), Izbrane teme iz vedenjsko-kognitivne terapije: zbornik 2 (str. 143162). Društvo za vedenjsko in koginitivno terapijo Slovenije.

\section{Empowerment while Solving Problems}

Main focus of psychological work is usually related to problems; both recognising them - as in a form of a mental disorder - or setting up interventions for their solving. Most of the time psychologists deal with negative everyday issues and can easily miss the focus on strengths, values and qualities of individuals. Also when making own personal reflections, psychologists tend to focus on things that they are not happy with rather then the opposite. There are times of procrastination at work and times of overworking to achieve the perfection. This gives us less opportunities to recognise how we have used our capacities (knowledge, wisdom, relationships establishes, good judgement of the situation, having strength to implement, were humane, fair or recognised beauty of meaning) in the best possible ways. Personal strengths can be divided into subgroups if they focus on inter- or intra-personal characteristics and according to their cognitive and emotional elements. Knowing these we can evaluate ourselves and our work in a new - more positive - way. 